OPEN ACCESS

Edited by:

Patrick Meir,

Australian National University, Australia

Reviewed by:

Mitsutoshi Kitao,

Forestry and Forest Products

Research Institute, Japan

Ze-Xin Fan,

Xishuangbanna Tropical Botanical

Garden (CAS), China

${ }^{*}$ Correspondence:

Johan Uddling

johan.uddling@bioenv.gu.se

Specialty section:

This article was submitted to

Functional Plant Ecology,

a section of the journal

Frontiers in Plant Science

Received: 25 September 2019

Accepted: 31 August 2020

Published: 17 September 2020

Citation:

Ziegler $C$, Dusenge $M E$,

Nyirambangutse B, Zibera E, Wallin $G$ and Uddling J (2020) Contrasting Dependencies of Photosynthetic

Capacity on Leaf Nitrogen in Earlyand Late-Successional Tropical

Montane Tree Species.

Front. Plant Sci. 11:500479. doi: 10.3389/fp/s.2020.500479

\section{Contrasting Dependencies of Photosynthetic Capacity on Leaf Nitrogen in Early- and Late- Successional Tropical Montane Tree Species}

\author{
Camille Ziegler ${ }^{1,2,3}$, Mirindi Eric Dusenge ${ }^{1,4,5}$, Brigitte Nyirambangutse ${ }^{1,4}$, Etienne Zibera ${ }^{4}$, \\ Göran Wallin ${ }^{1}$ and Johan Uddling ${ }^{1 *}$ \\ ${ }^{1}$ Department of Biological and Environmental Sciences, University of Gothenburg, Gothenburg, Sweden, ${ }^{2}$ UMR EcoFoG, \\ AgroParisTech, CNRS, CIRAD, INRAE, Université des Antilles, Université de Guyane, Kourou, France, ${ }^{3}$ Université de \\ Lorraine, AgroParisTech, INRAE, UMR Silva, Nancy, France, ${ }^{4}$ Department of Biology, University of Rwanda, Huye, Rwanda, \\ ${ }^{5}$ Department of Biology, The University of Western Ontario, London, ON, Canada
}

Differences in photosynthetic capacity among tree species and tree functional types are currently assumed to be largely driven by variation in leaf nutrient content, particularly nitrogen ( $\mathrm{N}$ ). However, recent studies indicate that leaf $\mathrm{N}$ content is often a poor predictor of variation in photosynthetic capacity in tropical trees. In this study, we explored the relative importance of area-based total leaf $\mathrm{N}$ content $\left(\mathrm{N}_{\text {tot }}\right)$ and within-leaf $\mathrm{N}$ allocation to photosynthetic capacity versus light-harvesting in controlling the variation in photosynthetic capacity (i.e. $V_{\mathrm{cmax}}, J_{\max }$ ) among mature trees of 12 species belonging to either early (ES) or late successional (LS) groups growing in a tropical montane rainforest in Rwanda, Central Africa. Photosynthetic capacity at a common leaf temperature of $25^{\circ} \mathrm{C}$ (i.e. maximum rates of Rubisco carboxylation, $V_{\mathrm{cmax} 25}$ and of electron transport, $J_{\max 25}$ ) was higher in ES than in LS species (+ $58 \%$ and $68 \%$ for $V_{\mathrm{cmax} 25}$ and $J_{\max 25}$, respectively). While $N_{\text {tot }}$ did not significantly differ between successional groups, the photosynthetic dependency on $\mathrm{N}_{\text {tot }}$ was markedly different. In ES species, $V_{\text {cmax } 25}$ was strongly and positively related to $N_{\text {tot }}$ but this was not the case in LS species. However, there was no significant trade-off between relative leaf $N$ investments in compounds maximizing photosynthetic capacity versus compounds maximizing light harvesting. Both leaf dark respiration at $25^{\circ} \mathrm{C}(+33 \%)$ and, more surprisingly, apparent photosynthetic quantum yield (+35\%) was higher in ES than in LS species. Moreover, $\mathrm{R}_{\mathrm{d} 25}$ was positively related to $\mathrm{N}_{\text {tot }}$ for both ES and LS species. Our results imply that efforts to quantify carbon fluxes of tropical montane rainforests would be improved if they considered contrasting within-leaf $\mathrm{N}$ allocation and photosynthetic $\mathrm{N}_{\text {tot }}$ dependencies between species with different successional strategies.

Keywords: photosynthesis, nitrogen, allocation, early successional, late successional, tropical montane forests 


\section{INTRODUCTION}

Tropical forests play an important role in controlling the global carbon cycle and, thus, the rate of ongoing climate change (Lewis, 2006; Stocker et al., 2014). They store more than half of the carbon in the world's forests (Pan et al., 2011), and provide roughly one-third of the global terrestrial primary production (Beer et al., 2010). Reliable quantification of the carbon uptake of tropical forests across time and space thus requires understanding of how carbon fluxes (carbon gain through photosynthesis and carbon loss through respiration) vary among environmental conditions and tree functional types. More specifically, Dynamic Global Vegetation Models (DGVMs) and Earth System Models (ESMs) require accurate representation of the factors controlling variation in the maximum rates of photosynthetic carboxylation $\left(V_{\text {cmax }}\right)$ and electron transport $\left(J_{\max }\right)$, as well as leaf respiration (Rogers, 2014; Walker et al., 2014). For tropical forests in general and African rainforests and tropical montane forests in particular, much remains to be explored regarding these controls.

Most DGVMs and ESMs employ the photosynthesis model by Farquhar et al. (1980), which represents the variation in $V_{\text {cmax }}$ and $J_{\max }$ (at a reference temperature) as either fixed values for different plant functional types or as linear functions of areabased total leaf nitrogen content $\left(\mathrm{N}_{\text {tot; }}\right.$ Kattge et al., 2009; Thornton et al., 2009; Zaehle et al., 2010; Rogers, 2014; Walker et al., 2014). However, a recent global meta-analysis found that interspecific variation in $V_{\text {cmax }}$ and $J_{\max }$ was much more closely related to photosynthetic $\mathrm{N}$ use efficiency than to $\mathrm{N}_{\text {tot }}$ (Ali et al., 2015). Moreover, several studies in tropical rainforests have found that area-based leaf nutrient content (i.e. N, phosphorous) is often a poor predictor of the large interspecific variation in photosynthetic capacity (Coste et al., 2005; van de Weg et al., 2012; Houter and Pons, 2014; Dusenge et al., 2015; Bahar et al., 2016; Hasper et al., 2017). Some of these studies have indicated that the fractional investment of leaf $\mathrm{N}$ into compounds maximizing photosynthetic capacity (i.e. $V_{c \max }$ and $J_{\max }$ ) is a considerably stronger determinant of interspecific variation in $V_{\text {cmax }}$ and $J_{\max }$ than $\mathrm{N}_{\text {tot }}$ (Coste et al., 2005; Dusenge et al., 2015; Hasper et al., 2017). Yet, more research is needed to confirm this pattern since these studies were conducted on seedlings in a greenhouse (Coste et al., 2005) or on a rather small number of rainforest tree species (six in Dusenge et al., 2015; five in Hasper et al., 2017). The strength of the relationship between photosynthesis and $\mathrm{N}_{\text {tot }}$ may depend on leaf phosphorus (P) content (Reich et al., 2009). However, $V_{\text {cmax }}-\mathrm{N}$ relationships were similarly weak at both high and lower altitude in Rwanda, in spite of leaf $\mathrm{P}$ content being twice as high at the higher site (Dusenge et al., 2015). Furthermore, leaf P content and photosynthetic $\mathrm{N}$ use efficiency $\left(V_{\text {cmax }}\right.$ per unit leaf $\left.\mathrm{N}\right)$ were not correlated in a large study of Andean and Amazonian rainforest species (Bahar et al., 2016).

Part of the reason for why interspecific variation in photosynthetic capacity is often poorly related to total leaf nutrient content may be that species with different successional strategies differ in within-leaf $\mathrm{N}$ allocation. Fast-growing and short-lived early-successional (ES) tree species usually make greater investments in $\mathrm{N}$-rich molecules involved in photosynthesis and respiration than slow-growing and longlived late-successional (LS) tree species, regenerating in low light under tree canopies (Raaimakers et al., 1995; Valladares and Niinemets, 2008; Xiao et al., 2018). In contrast, leaves of LS species are often more long-lived and make larger fractional investments in rather $\mathrm{N}$-poor structural compounds and pigmentation. However, these patterns do not always hold true for tropical tree species. A study with seedlings of 14 rainforest species found that while leaf mass per unit leaf area (LMA) increased with species' shade tolerance, photosynthetic capacity and $\mathrm{N}_{\text {tot }}$ content did not systematically change (Coste et al. (2005). Another study on 17 rainforest tree species, reported that photosynthetic capacity decreased with increasing species' shade tolerance while LMA and $\mathrm{N}_{\text {tot }}$ did not change (Houter and Pons, 2014). These studies thus suggest that interspecific variation in photosynthetic capacity in tropical trees is often controlled by within-leaf $\mathrm{N}$ allocation, but more research is needed to explore the link between within-leaf $\mathrm{N}$ allocation strategies and other plant traits (e.g., other leaf traits, life history traits).

A recent study on six tropical montane rainforest tree species indicated that there may be a trade-off involved in within-leaf $\mathrm{N}$ allocation, such that ES species with high fractional $\mathrm{N}$ investments into compounds that maximize photosynthetic capacity (i.e. $V_{\text {cmax }}$ and $J_{\max }$ ) invest less $\mathrm{N}$ into compounds involved in light-harvesting (i.e., chlorophyll and photosystems), and vice versa for LS species (Dusenge et al., 2015). Such differences between ES and LS species are in line with the "carbon gain hypothesis" put forward to explain plant shadetolerance. It states that shade-tolerant LS species have plant traits that maximize carbon gain under low light conditions (e.g., low respiration and LMA, high chlorophyll content and quantum yield of photosynthesis; Valladares and Niinemets, 2008). However, the study by Dusenge et al. (2015) found that LS species, in spite of indications of higher chlorophyll content, actually had significantly lower quantum yield than ES species. Clearly, more research is needed to better understand the roles played by different plant traits in controlling shade-tolerance in tropical forests (Valladares et al., 2016; Poorter et al., 2019).

Africa harbors 27\% of all tropical forests (Scatena et al., 2010) and $13 \%$ of all tropical montane forests (elevation > $1000 \mathrm{~m}$ a.s.l; Spracklen and Righelato, 2014). However with respect to ecological and biogeochemical understanding of carbon dynamics, the available data on African tropical forests is scarce, mainly due to the lack of an extensive long-term observation network (Lewis et al., 2009). This is particularly the case for mountainous ecosystems (Mountain Research Initiative EDW working group; Pepin et al., 2015). Here, we investigated physiological, chemical and structural properties of leaves in mature individuals belonging to 12 tree species-five ES and seven LS species-growing in one of Africa's largest remaining tropical montane rainforests, Nyungwe forest in Rwanda. The overall aim of this study was to explore the controls of interspecific variation in photosynthetic capacity and other leaf gas exchange traits in tropical montane rainforest tree species. Based on previous research, the following predictions were tested: 
1. ES species have higher photosynthetic capacity (higher $V_{\mathrm{cmax}}$, and $J_{\max }$ ) than LS species;

2. Area-based total leaf $\mathrm{N}$ content is a poor predictor of photosynthetic capacity;

3. Successional groups differ in their within-leaf $\mathrm{N}$ allocation;

4. There is a trade-off in the allocation of leaf $\mathrm{N}$ between investments into compounds maximizing photosynthetic capacity versus compounds maximizing light harvesting;

5. Key predictions of the "carbon-gain hypothesis" do not apply to montane rainforest tree species.

A previous study in Nyungwe forest showed that neither intra- nor interspecific variation in photosynthetic capacity was related to leaf $\mathrm{P}$ content (Dusenge et al., 2015), which was not investigated here.

\section{MATERIALS AND METHODS}

\section{Study Site and Plant Species}

Data were collected on mature trees (Table 1) in Nyungwe National Park $\left(2^{\circ} 17-2^{\circ} 49^{\prime}\right.$ S, $29^{\circ} 03-29^{\circ} 29^{\prime}$ E; elevation $1600-$ $2950 \mathrm{~m}$, investigated plots at 1950-2500 m). Nyungwe National Park (hereafter called "Nyungwe") is located in the southwestern part of Rwanda, Central Africa, within the Albertine Rift ecoregion (Plumptre et al., 2007). Nyungwe covers $1013 \mathrm{~km}^{2}$ and forms, together with the contiguous Kibira national park in Burundi, the largest block of tropical mi-elevation montane forest remaining in Africa, with large areas encompassing a mixture of primary and secondary forest due to its disturbance history (Plumptre et al., 2002).

At a meteorological station located at Uwinka ( $2^{\circ} 28^{\prime} 43^{\prime \prime} \mathrm{S}, 29^{\circ}$ 12’00” E, $2465 \mathrm{~m}$ altitude; Nsabimana, 2009; Nyirambangutse et al., 2017), the average day and night air temperatures during 2007-2015 were $15.8^{\circ} \mathrm{C}$ and $13.5^{\circ} \mathrm{C}$, respectively, and the difference between the warmest and coldest month was $1.1^{\circ} \mathrm{C}$. The mean relative humidity was $84 \%$ and annual rainfall was $1855 \mathrm{~mm}$.
Nyungwe harbors more than 260 tree and shrub species, with 24 recorded as endemic to the Albertine rift (Plumptre et al., 2002). The 12 species investigated in this study were selected to represent common ES and LS species, according to data from 15 half ha monitoring plots recently established in the forest (Table 2 in Nyirambangutse et al., 2017). The most abundant ES and LS species in Nyungwe are Macaranga kilimandscharica and Syzigium guineense, respectively, each accounting for $18 \%$ of the total number of trees with a diameter at breast height $\geq 30 \mathrm{~cm}$ according to a forest-wide survey (Plumptre et al., 2002). The other ES species co-occurred with M. kilimandscharica, except $H$. abyssisnica which was found at edges and gaps, while the five of the six other LS species clearly co-occurred with S. guineense. Ocotea kenyensis occurred together with both M. kilimandscharica and $S$. guineense but has been described as a LS species in the literature (Tesfaye et al., 2002). It was present mostly as rather large trees in our plots, indicating that when co-occurring with $M$. kilimandscharica it might be a survivor of earlier disturbance events. The 12 studied species together account for $76 \%$ of the total basal area of all trees with diameter at breast height $\geq 5 \mathrm{~cm}$ in the 15 monitoring plots (Table 1).

\section{Leaf Gas Exchange Measurements}

Field measurements of leaf gas exchange in mature trees were conducted from late February to early August 2015 between 9:00 and 17:00 h, using two portable leaf gas exchange instruments (LI6400; LI-COR Inc., Lincoln, NE, USA) with the standard $2 \mathrm{~cm} \times 3 \mathrm{~cm}$ leaf chamber and a light source (640002B LED Light Source). Fully expanded newly mature sun leaves without visible damage were selected and measured for responses of net photosynthetic rate $\left(A_{n}\right)$ to eight $\mathrm{CO}_{2}$

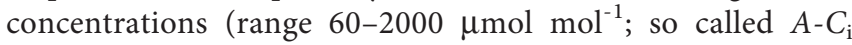
curves) at a photosynthetic photon flux density (PPFD) of $1800 \mu \mathrm{mol} \mathrm{m} \mathrm{m}^{-2} \mathrm{~s}^{-1}$. Then, $A_{\mathrm{n}}$ was measured at five different levels of PPFD $\left(0,25,50,75\right.$, and $100 \mu \mathrm{mol} \mathrm{m} \mathrm{m}^{-2} \mathrm{~s}^{-1}$; so called light-response curves) at a $\mathrm{CO}_{2}$ concentration of $400 \mu \mathrm{mol}$ $\mathrm{mol}^{-1}$ of air entering the leaf chamber. The relative air humidity was kept between $60 \%$ and $80 \%$ during the measurements to

TABLE 1 | Description of early-successional (ES) and late-successional (LS) tree species investigated in this study.

\begin{tabular}{|c|c|c|c|c|c|}
\hline Species & Family & Successional group ${ }^{a}$ & $\begin{array}{c}\text { Diameter at breast } \\
\text { height }(\mathbf{c m})\end{array}$ & $\% \mathrm{BA}$ in plots & Tree height $(\mathrm{m})$ \\
\hline Hagenia abyssinica (Bruce) J.F.Gmel. & Rosaceae & ES & $28 \pm 14$ & 0.3 & $8 \pm 5$ \\
\hline Harungana montana Spralet & Clusiaceae & ES & $41 \pm 21$ & 2.3 & $20 \pm 2$ \\
\hline Macaranga kilimandscharica Pax & Euphorbiaceae & ES & $22 \pm 5$ & 24.8 & $15 \pm 4$ \\
\hline Prunus africana (Hook. f.) Kalkm. & Rosaceae & ES & $35 \pm 13$ & 0.6 & $19 \pm 6$ \\
\hline Polyscias fulva (Hiern.) Harms & Araliaceae & ES & $52 \pm 13$ & 3.4 & $20 \pm 3$ \\
\hline Carapa grandiflora Sprague & Meliaceae & LS & $40 \pm 22$ & 2.6 & $19 \pm 5$ \\
\hline Cleistanthus polystachyus Hook.f. ex Planch. & Euphorbiaceae & LS & $31 \pm 15$ & 2.6 & $18 \pm 4$ \\
\hline Faurea Saligna Harv. & Proteaceae & LS & $53 \pm 21$ & 6.1 & $25 \pm 7$ \\
\hline Ficalhoa laurifolia Hiern. & Theaceae & LS & $37 \pm 12$ & 2.5 & $22 \pm 4$ \\
\hline Ocotea kenyensis (Chiov.) Robyns \& Wilczek & Lauraceae & LS & $40 \pm 18$ & 3.0 & $22 \pm 5$ \\
\hline Strombosia scheffleri Engl. & Olacaceae & LS & $31 \pm 10$ & 1.2 & $20 \pm 6$ \\
\hline Syzygium guineense (Willd.) DC. & Myrtaceae & LS & $50 \pm 21$ & 26.6 & $20 \pm 5$ \\
\hline
\end{tabular}

Means \pm SE are represented for $n=5-7$ species per successional group and $7-15$ trees per species.

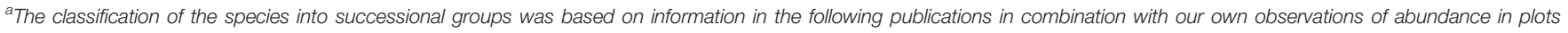

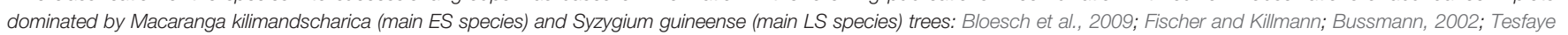
et al., 2002; Fashing, 2004; Fashing et al., 2004; Eilu and Obua, 2005; Kindt et al., 2014; Rutten et al., 2015. 
TABLE 2 | Summary report with results of a two-factor mixed-effects ANOVA and a linear mixed-effects model (see Statistical Analysis section).

\begin{tabular}{|c|c|c|c|}
\hline Parameter & Factor & F-value & p-value \\
\hline \multicolumn{4}{|c|}{ Mixed-effects ANOVA } \\
\hline$V_{\text {cmax } 25}$ & Succ & 9.8 & 0.011 \\
\hline$J_{\max 25}$ & Succ & 11.6 & 0.009 \\
\hline$J_{\max 25} / V_{c \max 25}$ & Succ & 0.2 & 0.66 \\
\hline$A_{280}$ & Succ & 9.4 & 0.012 \\
\hline AQY & Succ & 10.7 & 0.008 \\
\hline$R_{\mathrm{d} 25}$ & Succ & 6.9 & 0.025 \\
\hline $\mathrm{N}_{\text {tot }}$ & Succ & 0.4 & 0.54 \\
\hline LMA & Succ & 1.4 & 0.26 \\
\hline $\mathrm{Chl}$ & Succ & 1.6 & 0.23 \\
\hline \multicolumn{4}{|c|}{ Linear mixed-effects model } \\
\hline \multirow[t]{4}{*}{$V_{\mathrm{cmax} 25}$} & $\mathrm{~N}_{\text {tot }}$ & 0.67 & 0.41 \\
\hline & Succ & 8.7 & 0.015 \\
\hline & $\mathrm{N}_{\text {tot }}{ }^{\star S u c c}$ & 5.8 & 0.018 \\
\hline & $\mathrm{N}_{\llcorner\mathrm{H}}$ & 11.7 & 0.001 \\
\hline \multirow[t]{3}{*}{$\mathrm{N}_{\mathrm{R}+\mathrm{B}}$} & Succ & 4.2 & 0.067 \\
\hline & $\mathrm{N}_{\mathrm{LH}}{ }^{*} \mathrm{Succ}$ & 0.5 & 0.5 \\
\hline & $\mathrm{N}_{\text {tot }}$ & 7.14 & 0.009 \\
\hline \multirow[t]{2}{*}{$\mathrm{R}_{\mathrm{d} 25}$} & Succ & 7.14 & 0.023 \\
\hline & $\mathrm{N}_{\text {tot }}{ }^{\star S}$ ucc & 0.15 & 0.7 \\
\hline \multirow[t]{4}{*}{$N_{\text {tot }}$} & LMA & 72.2 & $<0.001$ \\
\hline & Succ & 0.0083 & 0.93 \\
\hline & $\mathrm{LMA}^{*}$ Succ & 1.5 & 0.22 \\
\hline & $\mathrm{N}_{\llcorner\mathrm{H}}$ & 5.7 & 0.019 \\
\hline \multirow[t]{2}{*}{ AQY } & Succ & 4.8 & 0.052 \\
\hline & $\mathrm{N}_{\mathrm{LH}}{ }^{*} \mathrm{Succ}$ & 2 & 0.16 \\
\hline
\end{tabular}

Bold numbers represent $p<0.05$. Traits analyzed were: maximum rates of Rubisco carboxylation capacity $\left(V_{c \max 25}, \mu \mathrm{mol} \mathrm{m} \mathrm{m}^{-2} \mathrm{~s}^{-1}\right)$ and electron transport $\left(\mathrm{J}_{\max 25}, \mu \mathrm{mol} \mathrm{m} \mathrm{m}^{-2} \mathrm{~s}^{-1}\right)$ at $25^{\circ} \mathrm{C}$; photosynthetic rates at a constant intercellular $\left(C_{i}\right) \mathrm{CO}_{2}$ concentration of $280 \mathrm{ppm}$ $\left(A_{280}, \mu \mathrm{mol} \mathrm{m}^{-2} \mathrm{~s}^{-1}\right)$; the ratio of $J_{\max 25}$ to $V_{c \max 25}\left(J_{\max 25}: V_{c \max 25}\right.$ ratio); leaf mass per unit leaf area ( $\left.L M A, g^{-2}\right)$ and area-based total leaf nitrogen content $\left(N_{\text {tot, }} g^{-2}\right)$; leaf dark respiration measured at $25^{\circ} \mathrm{C}$; apparent quantum yield of photosynthesis (AQY); fractional investments of total leaf $N$ content into compounds maximizing photosynthetic capacity $\left(N_{R+B}\right)$ and compounds maximizing photosynthetic light-harvesting $\left(N_{L H}\right)$.

avoid stomatal closure. Measurements of the response of $A_{\mathrm{n}}$ to $C_{\mathrm{i}}$ were performed only if the starting value of stomatal conductance $\left(g_{\mathrm{s}}\right)$ was above a minimal threshold of $0.03 \mathrm{~mol}$ $\mathrm{m}^{-2} \mathrm{~s}^{-1}$. Measurements of dark respiration $\left(R_{\mathrm{d}}\right)$ were conducted on a neighboring leaf, which had been covered by tinfoil and acclimated to darkness for a least $30 \mathrm{~min}$ prior to the measurement, to avoid post-illumination $\mathrm{CO}_{2}$ burst (Atkin et al., 1998). Most measurements were conducted at a leaf temperature of $20^{\circ} \mathrm{C}$, but 12 measurements conducted under unusually warm conditions were made at $25^{\circ} \mathrm{C}$.

Leaf gas exchange was measured on one leaf per tree in at least eight trees per species. The trees were selected from as many of the 15 forest plots as possible (some species were, however, present in only a few plots) to account for possible differences among plots (e.g., fertility). The total number of measured leaves was 116. Sun leaves were made accessible by cutting 1 to $2 \mathrm{~m}$ branches using a saw mounted on a $20 \mathrm{~m}$ long telescopic pole. The branches were immediately placed into a water-bucket prior to gas exchange measurements. The short-term effect of cutting was previously evaluated for Nyungwe tree species, showing no significant effect on $V_{\text {cmax }}$ and a quite small negative effect $(-8 \%$; $p<0.05$ ) on $J_{\max }$ (Dusenge et al., 2015). It was therefore unlikely that branch excision caused a sufficient disruption of xylem water continuity to substantially affect gas exchange measurements, as it may occur in some tropical tree species (Santiago and Mulkey, 2003).

After the measurement campaign from late February to April, it was found that a leak had been present in one of the two instruments used. The conductance of the leak was quantified and used to recalculate $A_{\mathrm{n}}$ and $C_{\mathrm{i}}$ data on the assumption that the $\mathrm{CO}_{2}$ concentration around the leaf chamber was $400 \mu \mathrm{mol} \mathrm{mol}{ }^{-1}$. Species-specific $V_{\text {cmax }}$ values determined for the adjusted data were very similar to the $V_{\mathrm{cmax}}$ values determined for data from the instrument without a leak (on average $1 \%$ difference). However, we refrain from reporting $J_{\max }$ data for the measurements affected by the leak since the leak correction was considerably larger at high compared to low $\mathrm{CO}_{2}$ concentrations inside the leaf chamber (e.g., about five times as large at $2000 \mu \mathrm{mol} \mathrm{mol}^{-1}$ than at $60 \mu \mathrm{mol} \mathrm{mol}{ }^{-1}$, at an ambient outside $\mathrm{CO}_{2}$ concentration of $400 \mu \mathrm{mol} \mathrm{mol}{ }^{-1}$ ). As result, we present no $J_{\max }$ data for two out of 12 species.

\section{Leaf Gas Exchange Data Analyses}

The photosynthesis model by Farquhar et al. (1980), with modifications of photosynthetic temperature dependencies by Bernacchi et al. (2001), was used to parameterize $V_{\text {cmax }}$ and $J_{\max }$ from $A-C_{\mathrm{i}}$ curve data by the least squares method. The rates of carboxylation-limited $\left(A_{\mathrm{c}}\right)$ and electron transport-limited net photosynthesis $\left(A_{\mathfrak{j}}\right)$ were calculated as:

$$
A_{c}=\frac{V_{c \max }\left(C_{i}-\Gamma^{\star}\right)}{C_{i}+K_{c}\left(1+\frac{O}{K_{o}}\right)}-R_{l}
$$

and

$$
A_{j}=J \frac{C_{i}-\Gamma^{*}}{4 \quad C_{i}+8 \Gamma}=R_{l}
$$

where $C_{\mathrm{i}}$ is the leaf intercellular $\mathrm{CO}_{2}$ concentration, $K_{\mathrm{c}}$ and $K_{\mathrm{o}}$ are Michaelis-Menten constants for $\mathrm{CO}_{2}$ and $\mathrm{O}_{2}$, respectively; $\Gamma^{\star}$ is the $\mathrm{CO}_{2}$ compensation point in the absence of mitochondrial respiration; $R_{1}$ is the non-photorespiratory $\mathrm{CO}_{2}$ release in the light; and $J$ is the rate of electron transport. For $K_{\mathrm{c}}, K_{\mathrm{o}}$, and $\Gamma^{\star}$, the values at $25^{\circ} \mathrm{C}$ as well as the temperature sensitivities were taken from Bernacchi et al. (2001). The internal leaf conductance for $\mathrm{CO}_{2}$ was not estimated and therefore "apparent" $V_{\mathrm{cmax}}$ and $J_{\max }$ values are reported, based on $C_{\mathrm{i}}$ rather than on the $\mathrm{CO}_{2}$ concentration at the chloroplast. The parameterization of $V_{\mathrm{cmax}}$ and $J_{\max }$ were done based on partial pressure units $\left(\mathrm{P}_{\mathrm{a}}\right)$ of $\mathrm{CO}_{2}$ $\left(C_{\mathrm{i}}\right.$ and $\left.\Gamma^{\star}\right)$ and $\mathrm{O}_{2}$; not on mole-based units.

Values of $V_{\text {cmax }}, J$, and $R_{1}$ were determined simultaneously with the only a priori restriction made to the $A-C_{\mathrm{i}}$ fitting that data points with $C_{\mathrm{i}}$ below $100 \mu \mathrm{mol} \mathrm{mol}{ }^{-1}$ were forced to be $V_{\text {cmax }}$-limited. Values of $J_{\max }$ were estimated from $J$ as in Medlyn et al. (2002). The uncertainty of the values of the curvature of the light-response (0.9) and quantum yield of electron transport (0.3 mol electrons $\mathrm{mol}^{-1}$ photons) used when calculating $J_{\max }$ from $J$ has only a minor effect on the estimated value of $J_{\max }$ (Medlyn et al., 2002). Values of $J_{\max }$ were reported only if the $A_{\mathrm{j}}$ limited part of the $A-C_{\mathrm{i}}$ curve had at least two data points, or from one single data point if $C_{\mathrm{i}}>1000 \mu \mathrm{mol} \mathrm{mol}{ }^{-1}$ and/or $A_{\mathrm{j}}$ was 
at least $10 \%$ lower than $A_{\mathrm{c}}$ at the $C_{\mathrm{i}}$ value of that data point. These criteria caused the exclusion of only two $J_{\max }$ values. Lightsaturated net photosynthesis at a common $C_{\mathrm{i}}$ of $280 \mu \mathrm{mol} \mathrm{mol}{ }^{-1}$ $\left(A_{280}\right.$; assuming the intercellular to ambient $\mathrm{CO}_{2}$ concentration to be 0.7 ) was calculated based on the fitted photosynthesis model for each leaf. Values of $V_{\mathrm{cmax}}, J_{\max }$, and $A_{280}$ are reported for a reference leaf temperature of $25^{\circ} \mathrm{C}$ using temperature response equations from Bernacchi et al. (2001), although most measurements were conducted at $20^{\circ} \mathrm{C}$. Reported values of $R_{\mathrm{d}}$ were standardized to a leaf temperature of $25^{\circ} \mathrm{C}\left(R_{\mathrm{d} 25}\right)$ using a $\mathrm{Q}_{10}$ value of 2.14, as suggested for tropical species (Atkin and Tjoelker, 2003).

The apparent (i.e. based on incident rather than absorbed radiation) quantum yield of photosynthesis was determined as the slope of the light-response curve in the PPFD range 25-50 $\mu \mathrm{mol} \mathrm{m} \mathrm{m}^{-1}$.

\section{Leaf Structural and Chemical Traits}

After gas exchange measurements, leaves were collected and the dry mass of leaf discs of known area was recorded after drying at $70^{\circ} \mathrm{C}$ until constant weight in order to calculate leaf mass per unit leaf area (LMA, $\mathrm{g} \mathrm{m}^{-2}$ ). Discs were then ground to fine powder in a ball mill, which was weighed and analyzed for $\mathrm{N}$ concentration using an elemental analyzer (EA 1108; Fison Instruments, Rodano, Italy).

Leaves were also measured for SPAD values, a proxy of leaf chlorophyll content (Uddling et al., 2007) optically measured using a SPAD meter (SPAD model 502; Minolta corporation, Ltd., Osaka, Japan). Ten evenly distributed readings were made across each leaf, again avoiding major veins. Leaf chlorophyll content was estimated from SPAD measurements using an equation for tropical tree species provided by Coste et al. (2010).

\section{Within-Leaf N Allocation}

The leaf $\mathrm{N}$ investments were determined for the following components of the photosynthetic apparatus: Rubisco $\left(\mathrm{N}_{\mathrm{R}}\right)$; bioenergetics, including coupling factors, electron carriers except for photosystems, and Calvin-Benson cycle enzymes except for Rubisco $\left(\mathrm{N}_{\mathrm{B}}\right)$; and light-harvesting complexes and photosystems $\left(\mathrm{N}_{\mathrm{LH}}\right)$.

The $\mathrm{N}_{\mathrm{R}}$ was estimated using the equation and parameters provided by (Niinemets and Tenhunen, 1997):

$$
N_{R}=\frac{0.160 V_{c \max }}{V_{c r}}
$$

where $V_{c \max }$ is the maximum rate of carboxylation, 0.160 converts Rubisco to $\mathrm{N}$ [g $\mathrm{N}$ in Rubisco (g Rubisco) ${ }^{-1}$ ] and $V_{\mathrm{cr}}$ the specific activity of Rubisco at $25^{\circ} \mathrm{C}\left[20.78 \mu \mathrm{mol} \mathrm{CO}_{2}(\mathrm{~g}\right.$ Rubisco $)^{-1} \mathrm{~s}^{-1}$.

The $\mathrm{N}_{\mathrm{B}}$ was estimated as:

$$
N_{B}=\frac{J_{\max }}{156 \times 8.06}
$$

where it is assumed that $\mathrm{N}$ in bioenergetics is proportional to $J_{\max }$, that 156 is the ratio of electron transport to cytochrome $\mathrm{f}$ content in $\mathrm{mol} \mathrm{mol}^{-1} \mathrm{~s}^{-1}$ and that 8.06 is the amount of cytochrome f per unit $\mathrm{N}$ in bioenergetics in $\mu \mathrm{mol} \mathrm{g}{ }^{-1}$ (Niinemets and Tenhunen, 1997). The sum of $\mathrm{N}_{R}$ and $\mathrm{N}_{B}\left(\mathrm{~N}_{\mathrm{R}+\mathrm{B}}\right)$ was used as a measure of leaf $\mathrm{N}$ in compounds determining the maximum photosynthetic rate, i.e. photosynthetic capacity

The $\mathrm{N}_{\mathrm{LH}}$ was estimated according to Evans and Poorter (2001) as:

$$
N_{L H}=41 \times 0.0155 \times C h l
$$

where $C h l$ is the area-based chlorophyll content $\left(\mathrm{g} \mathrm{m}^{-2}\right), 41$ is the $\mathrm{N}$ content per unit chlorophyll in light-harvesting complexes and photosystems in sun exposed leaves in $\mathrm{mol} \mathrm{mol}^{-1}$, and 0.0155 is the molar mass ratio of $\mathrm{N}$ to chlorophyll. We divided $\mathrm{N}_{\mathrm{R}+\mathrm{B}}$ and $\mathrm{N}_{\mathrm{LH}}$ by $\mathrm{N}_{\text {tot }}$ to get the fractional investments $\left(\mathrm{g} \mathrm{g}^{-1}\right)$ to compounds maximizing photosynthetic capacity and light harvesting, respectively.

For leaves lacking $J_{\max }$ data (see Leaf Gas Exchange Measurements section above), $\mathrm{N}_{\mathrm{B}}$ was estimated by assuming that these leaves had the same $J_{\max } / V_{\mathrm{cmax}}$ ratio as other leaves of the same species for which $J_{\max }$ data were available. In two species lacking $\mathrm{J}_{\max }$ data altogether, the $\mathrm{J}_{\max } / \mathrm{V}_{\mathrm{cmax}}$ ratio was assumed to be the mean of all other species (which did not significantly differ among the other species or between ES and LS species). The fraction of the total leaf $\mathrm{N}$ was markedly smaller for $\mathrm{N}_{\mathrm{B}}(4 \%)$ than for $\mathrm{N}_{\mathrm{R}}(21 \%)$, causing small uncertainty in the estimation of $\mathrm{N}_{\mathrm{R}+\mathrm{B}}$ introduced by this $\mathrm{N}_{\mathrm{B}}$ data gap filling.

\section{Statistical Analysis}

To analyze the effect of successional identity on photosynthetic capacity $\left(V_{\mathrm{cmax} 25}, J_{\max 25}\right.$ and $J_{\max 25} / V_{\mathrm{cmax} 25}$ ratio), $R_{\mathrm{d} 25}, \mathrm{AQY}$, LMA, chlorophyll content, and $\mathrm{N}_{\text {tot }}$, we used a two-factor mixedeffects ANOVA, with successional identity as a main factor and species as a random factor nested within successional group. The relationship between $V_{\mathrm{cmax} 25}$ and $\mathrm{N}_{\text {tot }}$ was analyzed with a linear mixed-effects model following Zuur et al. (2009) with $V_{\text {cmax25 }}$ as response variable, successional identity as a categorial factor, $\mathrm{N}_{\text {tot }}$ as a covariate, and species as a random factor with trees as replicates. We had five and seven species for early- and latesuccessional (Table 1), respectively, and for each species 7-15 trees were measured. Differences were considered statistically significant if $p<0.05$. All analyses were performed in $\mathrm{R}$ (version 3.5.2), and the following packages were used: lme4 (for mixedeffects modelling), dplyr (for data manipulation), and ggplot2 and cowplot (for graphing).

\section{RESULTS}

Basal rates of photosynthetic capacity (i.e. $V_{\mathrm{cmax} 25}$ and $J_{\max 25}$ ) differed between ES and LS species. $V_{\mathrm{cmax} 25}$ was $58 \%$ higher in ES $\left(71 \pm 9 \mu \mathrm{mol} \mathrm{m}{ }^{-2} \mathrm{~s}^{-1}\right)$ than in LS $\left(45 \pm 3 \mu \mathrm{mol} \mathrm{m} \mathrm{m}^{-2} \mathrm{~s}^{-1}\right)$ species (Figure 1A; Table 2). Similarly, $J_{\max 25}$ was $68 \%$ higher in ES (171 \pm $\left.21 \mu \mathrm{mol} \mathrm{m}^{-2} \mathrm{~s}^{-1}\right)$ than in LS $\left(102 \pm 6 \mu \mathrm{mol} \mathrm{m}^{-2} \mathrm{~s}^{-1}\right)$ species (Figure 1B). Values of $A_{280}$ were $58 \%$ higher in ES $\left(14 \pm 2 \mu \mathrm{mol} \mathrm{m} \mathrm{m}^{-2} \mathrm{~s}^{-1}\right)$ than LS $\left(9 \pm 1 \mu \mathrm{mol} \mathrm{m} \mathrm{m}^{-2}\right)$ species (Figure 1C). The $J_{\max 25} /$ $V_{\text {cmax25 }}$ ratio (2.4 across all species) was not statistically significant between ES and LS species, despite the relatively larger difference 
in $J_{\max 25}$ compared to $V_{\mathrm{cmax} 25}$ between ES and LS species (Figure 1D). Leaf dark respiration at $25^{\circ} \mathrm{C}\left(\mathrm{R}_{\mathrm{d} 25}\right)$ was $33 \%$ higher in $\mathrm{ES}(1.6$ $\left.\pm 0.1 \mu \mathrm{mol} \mathrm{m} \mathrm{m}^{-2} \mathrm{~s}^{-1}\right)$ compared to LS species $\left(1.2 \pm 0.1 \mu \mathrm{mol} \mathrm{m} \mathrm{m}^{-2} \mathrm{~s}^{-1}\right)$

(Figure 2A, Table 2). Similarly, apparent photosynthetic quantum yield (AQY) was $35 \%$ higher in ES $\left(0.042 \pm 0.003 \mathrm{~mol} \mathrm{~mol}^{-1}\right.$ photon) than in LS $\left(0.031 \pm 0.003 \mathrm{~mol} \mathrm{~mol}^{-1}\right.$ photon $)$ species (Figure 2B). Additionally, neither total leaf nitrogen $\left(\mathrm{N}_{\text {tot }}, 2.4 \mathrm{~g} \mathrm{~m}\right.$ 2 across all species), nor LMA (128 $\left.\mathrm{g} \mathrm{m}^{-2}\right)$, nor chlorophyll content $\left(0.84 \mathrm{~g} \mathrm{~m}^{-2}\right)$ differed between ES and LS groups (Figure 3; Table 2; Supplementary Table 2).
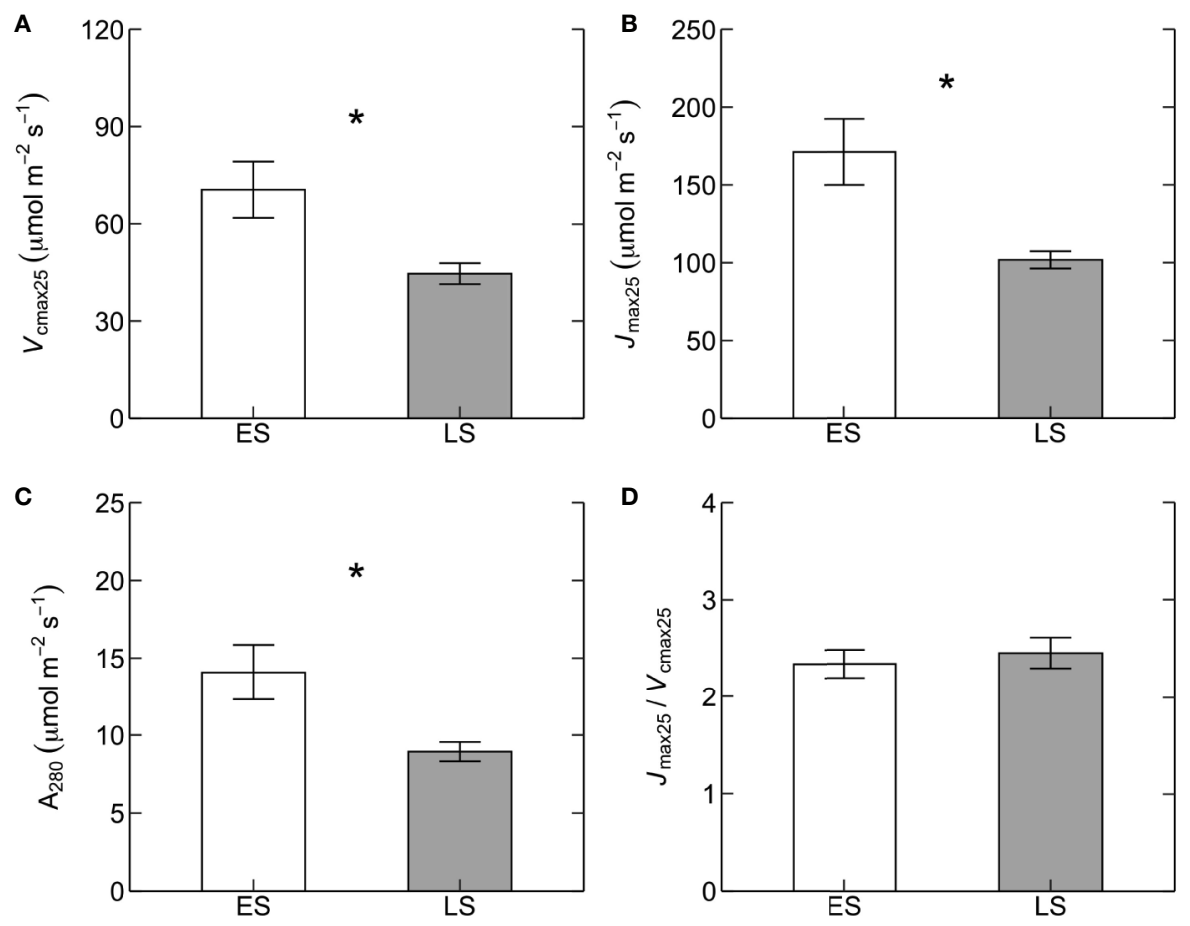

FIGURE 1 | Photosynthetic traits at $25^{\circ} \mathrm{C}$. Maximum rates of (A) Rubisco carboxylation capacity $\left(V_{c m a x} 25, \mu m o l ~ m^{-2} \mathrm{~s}^{-1}\right)$ and (B) electron transport $\left(J_{\max 25}, \mu\right.$ mol $\mathrm{m}^{-2}$ $\left.\mathrm{s}^{-1}\right)$, (C) photosynthetic rates at a constant intercellular $\mathrm{CO}_{2}$ concentration $\left(\mathrm{C}_{\mathrm{i}}\right)$ of $280 \mathrm{ppm}\left(A_{280}, \mu \mathrm{mol} \mathrm{m} \mathrm{m}^{-2} \mathrm{~s}^{-1}\right)$, and (D) the ratio of $J_{\max 25}$ to $V_{\mathrm{cmax} 25}\left(J_{\max 25} / V_{\mathrm{cmax} 25}\right)$ in early-successional (ES, white) versus late-successional (LS, gray) tree species in Nyungwe forest. The asterisks (in $\mathbf{A}-\mathbf{C})$ indicate statistical significance $(p<0.05)$. Error bars represent SE with $n=5-7$ species per successional group and $7-15$ trees per species.
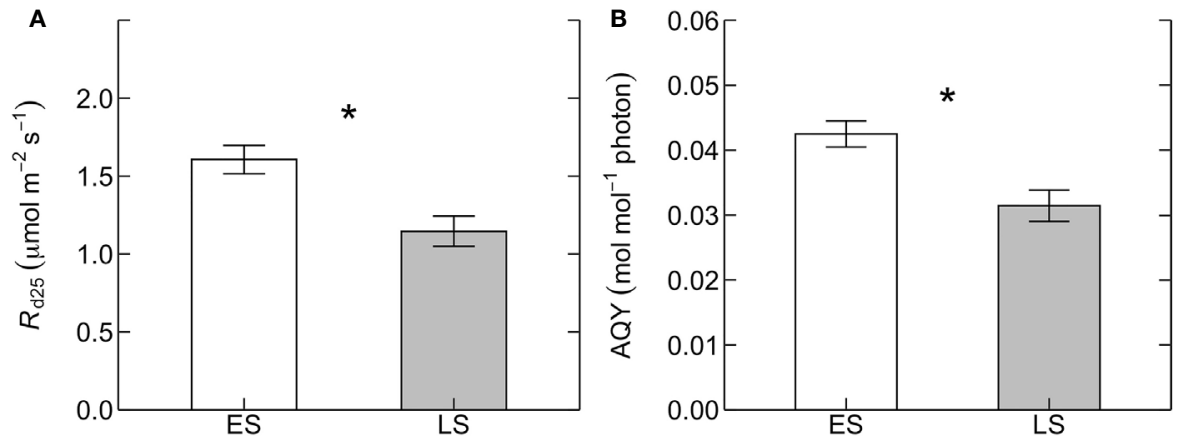

FIGURE 2 | (A) Leaf dark respiration measured at $25^{\circ} \mathrm{C}\left(R_{\mathrm{d} 25}, \mu \mathrm{mol} \mathrm{m} \mathrm{m}^{-2} \mathrm{~s}^{-1}\right)$ and (B) apparent quantum yield of photosynthesis (AQY, mol mol ${ }^{-1}$ photon) for earlysuccessional (ES, white) and late-successional (LS, gray) tree species in Nyungwe forest. The asterisks (in A, B) indicate statistical significance $(p<0.05)$. Error bars represent SE with $n=5-7$ species per successional group and 7-15 trees per species. 

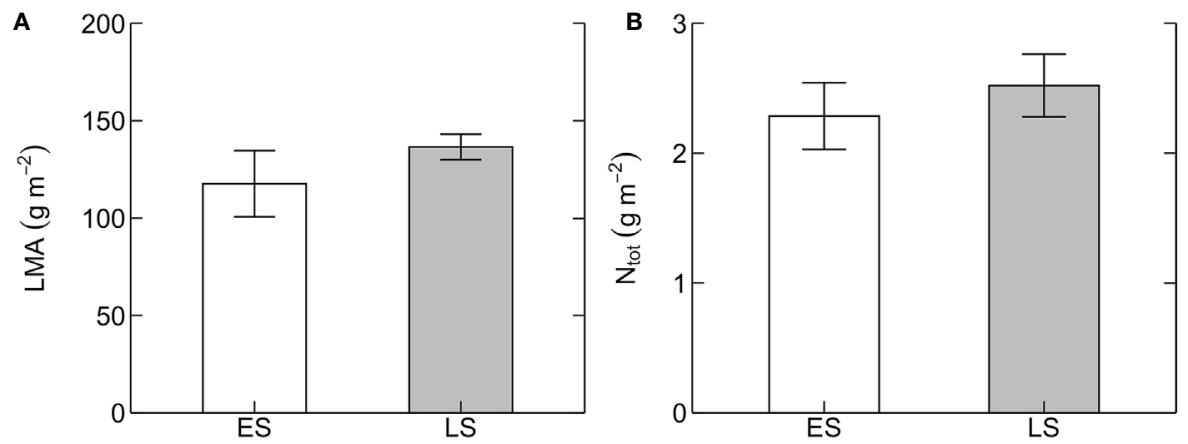

FIGURE 3 | Leaf structural and chemical traits. (A) Leaf mass per unit leaf area (LMA, $\left.\mathrm{g} \mathrm{m}^{-2}\right)$ and (B) area-based total leaf nitrogen content $\left(\mathrm{N}_{\text {tot }}, \mathrm{g} \mathrm{m}^{-2}\right)$ in earlysuccessional (ES, white) and late-successional (LS, gray) tree species in Nyungwe forest. Error bars represent SE with $n=5-7$ species per successional group and 7-15 trees per species.

The relationship between $V_{\text {cmax } 25}$ and $\mathrm{N}_{\text {tot }}$ differed between ES and LS species (Figure 4; Table 2). In ES species, $V_{\mathrm{cmax} 25}$ increased with $\mathrm{N}_{\text {tot }}$, while in LS species there was no such dependency at all. At low $\mathrm{N}_{\text {tot }}\left(\sim 1 \mathrm{~g} \mathrm{~m}^{-2}\right), V_{\mathrm{cmax} 25}$ was similar in both groups. At higher $\mathrm{N}_{\text {tot }}$, however, $\mathrm{ES}$ species had considerably higher $V_{\mathrm{cmax} 25}$ than LS species and this difference increased progressively with the magnitude of $\mathrm{N}_{\text {tot }}$. However, $R_{\mathrm{d} 25}$ was positively related with $\mathrm{N}_{\text {tot }}$ for both ES and LS species, with similar slopes but different intercepts (Figure 5; Table 2).

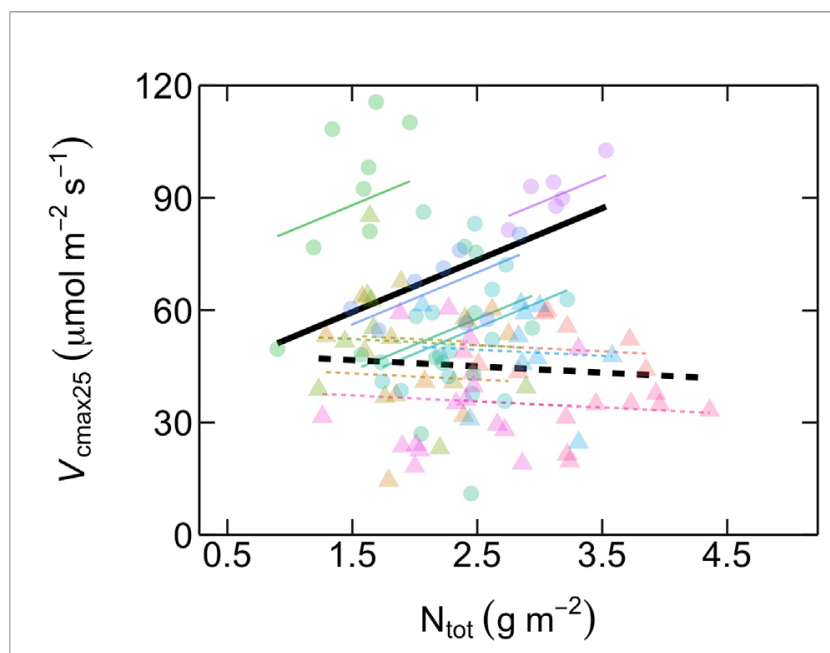

FIGURE 4 | Relationship between maximum rates of Rubisco carboxylation capacity at $25^{\circ} \mathrm{C}\left(V_{\mathrm{cmax} 25}, \mu \mathrm{mol} \mathrm{m} \mathrm{m}^{-2} \mathrm{~s}^{-1}\right)$ as a function of area-based total leaf nitrogen content $\left(\mathrm{N}_{\text {tot }}, \mathrm{g} \mathrm{m}^{-2}\right)$ in early-successional (ES) and late-successional (LS) tree species in Nyungwe forest. Different symbol colors represent each of the 12 studied species, and symbol shapes represent successional groups $\left(E S=\right.$ circle; $L S=$ triangle). Black solid $\left(E S: V_{\text {cmax } 25}=13.9 N_{\text {tot }}+38.6\right)$ and dashed (LS: $V_{\text {cmax } 25}=-1.6 N_{\text {tot }}+49.1$ ) lines are overall regression lines for ES and LS groups, respectively. Colored lines represent regression lines for each species belonging to ES (solid) and LS (dashed) groups, respectively, but with common successional group-specific slopes. $n=5-7$ species per successional group and $7-15$ trees per species.
There was a positive relationship between the fraction of total leaf $\mathrm{N}$ investments into compounds maximizing photosynthetic capacity $\left(\mathrm{N}_{\mathrm{R}+\mathrm{B}}\right)$ versus compounds involved in light-harvesting $\left(\mathrm{N}_{\mathrm{LH}}\right)$, with both ES and LS species displaying similar slopes (Figure 6, Table 2).

For both ES and LS species, $\mathrm{N}_{\text {tot }}$ was positively related to LMA (Supplementary Figure 1; Table 2). There was also a negative relationship between $\mathrm{N}_{\mathrm{LH}}$ and $\mathrm{AQY}$ for both groups, with similar slopes and a nearly significantly lower intercept $(p=0.052)$ for LS species (Supplementary Figure 2; Table 2).

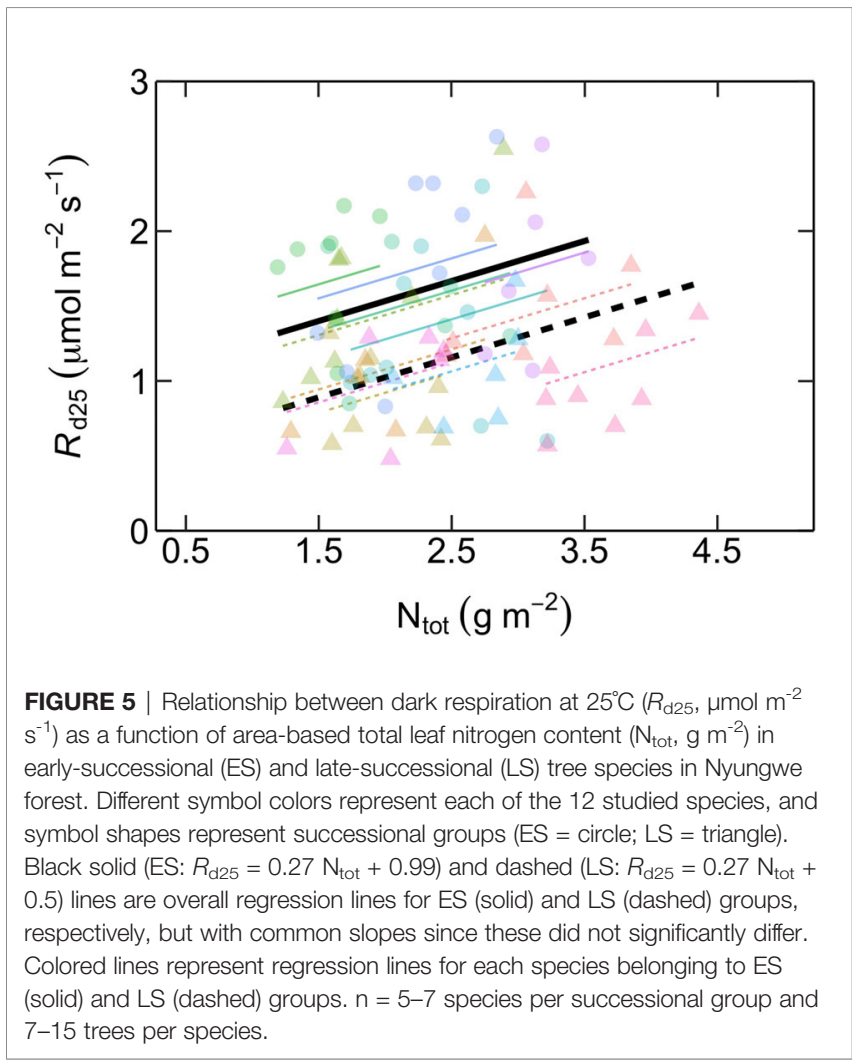




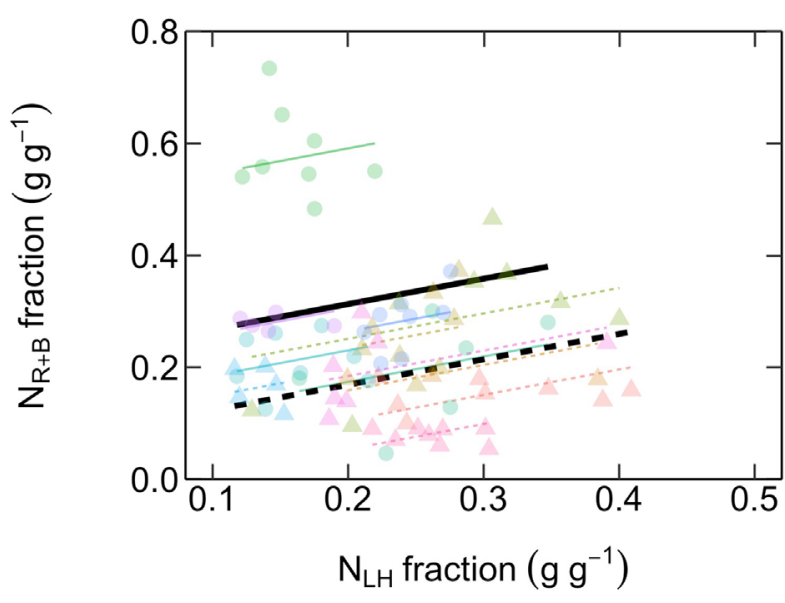

FIGURE 6 | Relationship between fractional investments of total leaf $\mathrm{N}$ content into compounds maximizing photosynthetic capacity $\left(N_{R+B}, g^{-1}\right)$ and compounds maximizing photosynthetic light-harvesting $\left(\mathrm{N}_{\mathrm{LH}}, \mathrm{g} \mathrm{g}^{-1}\right)$. Different symbol colors represent each of the 12 studied species, and symbol shapes represent successional groups ( $E S=$ circle; $L S=$ triangle). Black solid and dashed lines are overall regression lines for $E S\left(N_{R+B}=0.45 N_{L H}+0.22\right)$ and LS ( $\left.\mathrm{N}_{\mathrm{R}+\mathrm{B}}=0.45 \mathrm{~N}_{\mathrm{LH}}+0.08\right)$ groups, respectively, but with common slopes since these did not significantly differ. Colored lines represent regression lines for each species belonging to ES (solid) and LS (dashed) groups. $n=5-7$ species per successional group and $7-15$ trees per species.

\section{DISCUSSION}

With the overall aim to explore the controls of interspecific variation in photosynthetic capacity in tropical montane rainforest trees, we investigated physiological, morphological and chemical leaf traits in mature trees of 12 Central African montane rainforest tree species with contrasting light requirements. These species together represent about $60 \%$ of large trees (stem diameter at breast height $\geq 30 \mathrm{~cm}$ ) in Nyungwe forest-Africa's largest remaining midelevation montane rainforest block (Plumptre et al., 2002; Chao et al., 2011). The results highlight a marked difference in photosynthetic $\mathrm{N}$ dependency between different successional groups, with photosynthetic capacity strongly related to total areabased leaf $\mathrm{N}$ content (i.e. $\mathrm{N}_{\text {tot }}$ ) in ES species but not in LS species.

Photosynthetic capacity was markedly higher in ES compared to LS species (Figure 1). This difference was caused by strongly contrasting relative investments of leaf $\mathrm{N}$ to compounds maximizing photosynthetic capacity, since $\mathrm{N}_{\text {tot }}$ was similar in the two successional groups (Figure 3). These results confirm our first and third predictions. The second prediction, of poor dependency of photosynthetic capacity on $\mathrm{N}_{\text {tot }}$, was true for LS species but not for ES species (Figure 4). The lack of significant relationship in LS species is in line with other recent studies on tropical rainforest tree species (e.g. Coste et al., 2005; van de Weg et al., 2012; Houter and Pons, 2014; upland species: Bahar et al., 2016; Hasper et al., 2017; Gvozdevaite et al., 2018). However, it contrasts with a study in lowland forests of subtropical China showing a positive relationship between $\mathrm{N}_{\text {tot }}$ and photosynthetic capacity in LS species but not in ES species (Zhang et al., 2018).
Our results on LS species also differ from those of global metaanalyses demonstrating a significant positive relationship between $\mathrm{N}_{\text {tot }}$ and photosynthetic capacity in tropical trees (Kattge et al., 2009; Reich et al., 2009; Walker et al., 2014).

There are several possible reasons for why meta-analyses report positive relationships between $\mathrm{N}_{\text {tot }}$ and photosynthetic capacity while specific field studies do not. First, as we show here, photosynthetic $\mathrm{N}$ dependency seems strongly linked to species successional strategy (Figure 4). A field study focusing primarily on LS species may therefore not detect any significant relationship between $\mathrm{N}_{\text {tot }}$ and photosynthetic capacity while a meta-analysis including both ES and LS species would do so. Second, the metaanalyses included several studies that examined the canopy vertical variation in $\mathrm{N}_{\text {tot }}$ and photosynthetic capacity (Porté and Loustau, 1998; Carswell et al., 2000; Kumagai et al., 2001; Meir et al., 2002; Sholtis et al., 2004; Calfapietra et al., 2005; Domingues et al., 2005; Tissue et al., 2005). Since both $\mathrm{N}_{\text {tot }}$ and photosynthetic capacity are typically higher in sun leaves than in shade leaves this contributes to the overall relationship between the two variables in these studies (e.g. Carswell et al., 2000). Third, meta-analyses included data from tropical areas with large variation in soil fertility (both $\mathrm{N}$ and $\mathrm{P}$ ) while such variation is considerably lower in most specific field studies. This is well illustrated in a recent field study on 210 tree species from lowland Amazonian (lower soil fertility) and upland Andes (higher soil fertility) tropical rainforests, in which a significant relationship between photosynthetic capacity and leaf $\mathrm{N}_{\text {tot }}$ was found when data from both sites were pooled together (not necessarily a causal relationship since leaf $\mathrm{N}$ and $\mathrm{P}$ co-varied; Bahar et al., 2016). However, when trees from upland sites with high and fairly homogenous soil fertility were analyzed alone, no relationship between photosynthetic capacity and $\mathrm{N}_{\text {tot }}$ was found.

Our findings are in line with a recent global meta-analysis covering all types of plants and ecosystems which showed that within-leaf $\mathrm{N}$ allocation was a crucial determinant of variation in photosynthetic capacity (Ali et al., 2015). It further showed that about half of the variation in photosynthetic capacity could be attributed to environmental factors influencing photosynthetic $\mathrm{N}$ use efficiency (i.e. $V_{c \max }$ or $J_{\max }$ divided by $\mathrm{N}$ content). Our study suggests that successional group is another factor, not included in the meta-analysis of Ali et al. (2015), which may explain a significant part of variation in photosynthetic capacity. Our results suggest ES and LS species allocate equal fractions of leaf $\mathrm{N}$ into compounds maximizing photosynthetic capacity at low $\mathrm{N}_{\text {tot }}$, but that at higher $\mathrm{N}_{\text {tot }}$ ES species gradually increase their absolute $\mathrm{N}$ investments to photosynthetic capacity while LS species do not (Figure 4). These results are in agreement with the general understanding of how shade-intolerant ES species and shade-tolerant LS species differ with respect to leaf physiological traits related to carbon assimilation, i.e. that ES species prioritize high photosynthesis and rapid growth (Raaimakers et al., 1995; Hikosaka, 2004; Valladares and Niinemets, 2008; Reich, 2014). They provide novel insight by showing that the typical assumption of $\mathrm{N}_{\text {tot }}$ as a key determinant of photosynthetic capacity seems to hold for ES species but not for LS species, at least in tropical montane forests.

In contrast to the different relationships between $V_{\text {cmax } 25}$ and $\mathrm{N}_{\text {tot }}$ in ES and LS species, $R_{\mathrm{d} 25}$ was positively related to $\mathrm{N}_{\text {tot }}$ in both 
groups (Figure 5). This may reflect that, as $\mathrm{N}_{\text {tot }}$ increases, LS species invest the additional $\mathrm{N}$ at high $\mathrm{N}_{\text {tot }}$ into maintenance and secondary metabolism (i.e. defense) rather than into increased photosynthetic capacity (which did not increase; Figure 4).

The fourth prediction tested-that there is a trade-off in the allocation of leaf $\mathrm{N}$ between investments into compounds maximizing photosynthetic capacity versus compounds maximizing light harvesting-was not supported by our results (Figure 6). This hypothesis, proposed by Dusenge et al. (2015) and corroborated by Hasper et al. (2017), was based on their observations of a negative relationship between photosynthetic capacity (i.e. $\mathrm{V}_{\mathrm{cmax} 25}$ and $\mathrm{J}_{\max 25}$ ) and SPAD values (a proxy for area-based leaf chlorophyll content). In the current study, we further tested the hypothesis by explicitly investigating the possibility of a trade-off between fractional leaf $\mathrm{N}$ investments into Rubisco and bioenergetics $\left(\mathrm{N}_{\mathrm{R}+\mathrm{B}}\right)$ and light harvesting compounds $\left(\mathrm{N}_{\mathrm{LH}}\right)$. Strikingly, we found the opposite trend, suggesting that the hypothesis of Dusenge et al. (2015) may not be a general trade-off explaining species successional strategy. It is likely that there are other within-leaf $\mathrm{N}$ allocation trade-offs involved which were not investigated here. A recent meta-analysis (Onoda et al., 2017) revealed that the trade-off between photosynthetic $\mathrm{N}$ and structural $\mathrm{N}$ in cell walls, the two major leaf $\mathrm{N}$ pools, underlies the "leaf economics spectrum" (Wright et al., 2004; Hikosaka, 2004). However, this type of structure-function trade-off in $\mathrm{N}$ allocation is unlikely to explain the differences in the $V_{\text {cmax } 25}-\mathrm{N}_{\text {tot }}$ relationships between ES and LS species found in our study (Figure 4), since they did not differ in LMA or $\mathrm{N}_{\text {tot }}$ (Figure 3) and shared a common positive LMA$\mathrm{N}_{\text {tot }}$ relationship (SI Figure 1).

The fifth prediction tested-that key predictions of the "carbon-gain hypothesis" do not apply to montane rainforest tree species-was corroborated by our study. While photosynthetic capacity and $R_{\mathrm{d} 25}$ (as also seen in Baltzer and Thomas, 2007) differed in a way predicted by the carbon gain hypothesis (both lower in LS species), AQY, $\mathrm{N}_{\text {tot }}$, chlorophyll content, and LMA did not (Table 2). In complete contradiction with that hypothesis, AQY was even lower in LS compared to ES species, as also observed in a previous study on tropical montane trees species (Dusenge et al., 2015). Furthermore, our findings showed a negative relationship between AQY and $\mathrm{N}_{\mathrm{LH}}$ for both groups, implying that increased allocation of leaf $\mathrm{N}$ to light harvesting compounds does not necessarily improve light use efficiency, but rather the opposite. The lack of difference in LMA between LS and ES species was not surprising as it agrees with several studies on both mature and young tropical rainforest trees (e.g. Coste et al., 2005; Houter and Pons, 2014; Dusenge et al., 2015; Mujawamariya et al., 2018; Ntawuhiganayo et al., 2020). Some caution should be taken when interpreting observations on sun-exposed leaves of mature trees with respect to species shade tolerance in the understorey. However, since species ranking of leaf traits potentially linked to shade tolerance appears to be similar in sun and shade leaves of juvenile as well as mature tress (Rozendaal et al., 2006; Coste et al., 2009; Dusenge et al., 2015) our results likely have relevance for trees growing in the shade as well.

\section{Implications}

Most DGVMs and ESMs represent the variation in $V_{\mathrm{cmax}}$ and $J_{\max }$ (at a reference temperature) as either fixed values for different plant functional types or as linear functions of area-based leaf $\mathrm{N}$, i.e. $\mathrm{N}_{\text {tot }}$ (Kattge et al., 2009; Thornton et al., 2009; Zaehle et al., 2010; Rogers, 2014). Our finding of contrasting photosynthetic dependencies on $\mathrm{N}_{\text {tot }}$ in ES versus LS species suggests that both these approaches are problematic. Constant values for different plant functional types fail to account for factors that control variation in photosynthetic variation within each group, e.g. the variation in $\mathrm{N}_{\text {tot }}$ of $\mathrm{ES}$ species in the present study (Figure 4). The $\mathrm{N}_{\text {tot }}$ function concept, on the other hand, fails to recognize the lack of photosynthetic $\mathrm{N}$ dependency found for LS species. Our findings suggest that future model approaches would benefit from introducing a plant trait like within-leaf $\mathrm{N}$ allocation or photosynthetic $\mathrm{N}$ use efficiency. Such traits may be linked to environmental conditions, as reported earlier (Ali et al., 2015), and also to successional strategy, as found here. Our findings also provide important knowledge to improve the accuracy of smallerscale process-based models developed to estimate gross and net primary production in tropical montane rainforests. Recent work has supplied these models with a better understanding of the climatic variables and functional traits driving forest productivity, but they still currently suffer from large and unaccounted betweenspecies variation in photosynthetic capacity-leaf $\mathrm{N}$ relationships (van de Weg et al., 2014; Fyllas et al., 2017). Additionally, our results suggest that a better understanding of the controls of within-leaf nutrient allocation would contribute to a deeper understanding of plant strategies related to successional status and their position in the "fast-slow" plant economic spectrum (Reich, 2014).

\section{DATA AVAILABILITY STATEMENT}

The datasets generated for this study are available on request to the corresponding author.

\section{AUTHOR CONTRIBUTIONS}

CZ, MED, GW, and JU designed the study, CZ, MED, EZ, and $\mathrm{BN}$ collected the data, and $\mathrm{CZ}, \mathrm{MD}$, and JU analyzed the data. $\mathrm{CZ}, \mathrm{MED}$, and JU drafted the article using feedback from all coauthors. All authors contributed to the article and approved the submitted version.

\section{FUNDING}

This study was supported by the Strategic Research Area "Biodiversity and Ecosystem Services in a Changing Climate" (BECC; https://www.becc.lu.se/) and the University of RwandaSweden program for Research, Higher Education and Institutional Advancement, financed by Swedish International Development Cooperation Agency (Sida). Thanks also to IDEA WILD (http://www.ideawild.org) for a field laptop. The first author was also funded by Pôle A2F, Université de Lorraine, 
France, and the second author was also funded by the European Union's Horizon 2020 research and innovation programme under the Marie Sklodowska-Curie grant agreement No 844319.

\section{ACKNOWLEDGMENTS}

We are grateful to Innocent Rusizana and Pierre Niyontegereje for field assistance as well as Mats Räntfors for lab assistance.

\section{REFERENCES}

Ali, A. A., Xu, C., Rogers, A., McDowell, N. G., Medlyn, B. E., Fisher, R. A., et al. (2015). Global-scale environmental control of plant photosynthetic capacity. Ecol. Appl. 25, 2349-2365. doi: 10.1890/14-2111.1

Atkin, O. K., and Tjoelker, M. G. (2003). Thermal acclimation and the dynamic response of plant respiration to temperature. Trends Plant Sci. 8, 343-351. doi: 10.1016/S1360-1385(03)00136-5

Atkin, O. K., Evans, J. R., and Siebke, K. (1998). Relationship between the inhibition of leaf respiration by light and enhancement of leaf dark respiration following light treatment. Aust. J. Plant Physiol. 25, 437. doi: 10.1071/PP97159

Bahar, N. H. A., Ishida, F. Y., Weerasinghe, L. K., Guerrieri, R., O'Sullivan, O. S., Bloomfield, K. J., et al. (2016). Leaf-level photosynthetic capacity in lowland Amazonian and high-elevation Andean tropical moist forests of Peru. New Phytol. 214, 1002-1018. doi: 10.1111/nph.14079

Baltzer, J. L., and Thomas, S. C. (2007). Determinants of whole-plant light requirements in Bornean rain forest tree saplings. J. Ecol. 95, 1208-1221. doi: $10.1111 / j .1365-2745.2007 .01286 . x$

Beer, C., Reichstein, M., Tomelleri, E., Ciais, P., Jung, M., Carvalhais, N., et al. (2010). Terrestrial gross carbon dioxide uptake: global distribution and covariation with climate. Science 329, 834-838. doi: 10.1126/science. 1184984

Bernacchi, C. J., Singsaas, E. L., Pimentel, C., Portis, A. R. Jr., and Long, S. P. (2001). Improved temperature response functions for models of Rubiscolimited photosynthesis. Plant Cell Environ. 24, 253-259. doi: 10.1111/j.13653040.2001.00668.x

Bloesch, U., Troupin, G., and Derungs, N. (2009). Les plantes ligneuses du Rwanda Flore, ecologie et usages. (Shaker, Aachen).

Bussmann, R. W. (2002). Islands in the Desert-Forest Vegetation of Kenya'S Smaller Mountains and Highland Areas (Nyiru, Ndoto, Kulal, Marsabit, Loroghi, Ndare, Mukogodo, Porror, Mathews, Gakoe, Imenti, Ngaia, Nyambeni, Loita, Nguruman, Nairobi). J. East Afr. Natural Hist. 91, 27-79. doi: 10.2982/0012-8317(2002)91[27:IITDVO]2.0.CO;2

Calfapietra, C., Tulva, I., Eensalu, E., Perez, M., De Angelis, P., ScarasciaMugnozza, G., et al. (2005). Canopy profiles of photosynthetic parameters under elevated $\mathrm{CO} 2$ and $\mathrm{N}$ fertilization in a poplar plantation. Environ. Pollut. 137, 525-535. doi: 10.1016/j.envpol.2005.01.038

Carswell, F. E., Meir, P., Wandelli, E. V., Bonates, L. C. M., Kruijt, B., Barbosa, E. M., et al. (2000). Photosynthetic capacity in a central Amazonian rain forest. Tree Physiol. 20 (3), 179-186. doi: 10.1093/treephys/20.3.179

Chao, N., Mulindahabi, F., Easton, J., Plumptre, A. J., Seimon, A., Martin, A., et al. (2011). "Long term changes in a montane forest in a region of high population density," in The ecological impact of Long-term Changes in Africa's rift valley. Ed. A. J. Plumptre (New York: Nova Science), 167-202.

Coste, S., Roggy, J.-C., Imbert, P., Born, C., Bonal, D., and Dreyer, E. (2005). Leaf photosynthetic traits of 14 tropical rain forest species in relation to leaf nitrogen concentration and shade tolerance. Tree Physiol. 25, 1127-1137. doi: $10.1093 /$ treephys/25.9.1127

Coste, S., Roggy, J.-C., Garraud, L., Heuret, P., Nicolini, E., and Dreyer, E. (2009). Does ontogeny modulate irradiance-elicited plasticity of leaf traits in saplings of rain-forest tree species? A test with Dicorynia guianensis and Tachigali melinonii (Fabaceae, Caesalpinioideae). Ann. For. Sci. 66, 709-709. doi: $10.1051 /$ forest $/ 2009062$

Coste, S., Baraloto, C., Leroy, C., Marcon, É., Renaud, A., Richardson, A. D., et al. (2010). Assessing foliar chlorophyll contents with the SPAD-502 chlorophyll
We thank the Rwanda Development Board (RDB) which authorized data collection in the Nyungwe National Park.

\section{SUPPLEMENTARY MATERIAL}

The Supplementary Material for this article can be found online at: https://www.frontiersin.org/articles/10.3389/fpls.2020.500479/ full\#supplementary-material

meter: a calibration test with thirteen tree species of tropical rainforest in French Guiana. Ann. For. Sci. 67, 607-607. doi: 10.1051/forest/2010020

Domingues, T. F., Berry, J. A., Martinelli, L. A., Ometto, J. P. H. B., and Ehleringer, J. R. (2005). Parameterization of Canopy Structure and LeafLevel Gas Exchange for an Eastern Amazonian Tropical Rain Forest (Tapajós National Forest, Pará, Brazil). Earth Interact. 9, 1-23. doi: 10.1175/EI149.1

Dusenge, M. E., Wallin, G., Gårdesten, J., Niyonzima, F., Adolfsson, L., Nsabimana, D., et al. (2015). Photosynthetic capacity of tropical montane tree species in relation to leaf nutrients, successional strategy and growth temperature. Oecologia 177, 1183-1194. doi: 10.1007/s00442-015-3260-3

Eilu, G., and Obua, J. (2005). Tree condition and natural regeneration in disturbed sites of Bwindi Impenetrable Forest National Park, Southwestern Uganda. Trop. Ecol. 46 (1), 99-112.

Evans, J., and Poorter, H. (2001). Photosynthetic acclimation of plants to growth irradiance: the relative importance of specific leaf area and nitrogen partitioning in maximizing carbon gain. Plant Cell Environ. 24 (8), 755-767.

Farquhar, G. D., von Caemmerer, S., and Berry, J. A. (1980). A biochemical model of photosynthetic CO2 assimilation in leaves of C 3 species. Planta 149, 78-90. doi: 10.1007/BF00386231

Fashing, P. J., Forrestel, A., Scully, C., and Cords, M. (2004). Long-term tree population dynamics and their implications for the conservation of the Kakamega Forest, Kenya. Biodivers. Conserv. 13, 753-771. doi: 10.1023/B: BIOC.0000011724.34275.73

Fashing, P. J. (2004). Mortality trends in the African cherry (Prunus africana) and the implications for colobus monkeys (Colobus guereza) in Kakamega Forest, Kenya. Biol. Conserv. 120, 449-459. doi: 10.1016/j.biocon.2004. 03.018

Fischer, E., and Killmann, D. (2008). Illustrated field guide to the plants of Nyungwe National Park Rwanda. Koblenz Geographical Colloquia Series Biogeographical Monographs 1. (Koblenz, Koenigstein).

Fyllas, N. M., Bentley, L. P., Shenkin, A., Asner, G. P., Atkin, O. K., Díaz, S., et al. (2017). Solar radiation and functional traits explain the decline of forest primary productivity along a tropical elevation gradient. Ecol. Lett. 20, 730 740. doi: 10.1111/ele.12771

Gvozdevaite, A., Oliveras, I., Domingues, T. F., Peprah, T., Boakye, M., Afriyie, L., et al. (2018). Leaf-level photosynthetic capacity dynamics in relation to soil and foliar nutrients along forest-savanna boundaries in Ghana and Brazil. Tree Physiol. 38, 1912-1925. doi: 10.1093/treephys/tpy117

Hasper, T. B., Dusenge, M. E., Breuer, F., Uwizeye, F. K., Wallin, G., and Uddling, J. (2017). Stomatal CO2 responsiveness and photosynthetic capacity of tropical woody species in relation to taxonomy and functional traits. Oecologia 184, 4357. doi: 10.1007/s00442-017-3829-0

Hikosaka, K. (2004). Interspecific difference in the photosynthesis-nitrogen relationship: patterns, physiological causes, and ecological importance. J. Plant Res. 117, 481-494. doi: 10.1007/s10265-004-0174-2

Houter, N. C., and Pons, T. L. (2014). Gap effects on leaf traits of tropical rainforest trees differing in juvenile light requirement. Oecologia 175, 37-50. doi: 10.1007/ s00442-014-2887-9

Kattge, J., Knorr, W., Raddatz, T., and Wirth, C. (2009). Quantifying photosynthetic capacity and its relationship to leaf nitrogen content for global-scale terrestrial biosphere models. Glob. Change Biol. 15, 976-991. doi: 10.1111/j.1365-2486.2008.01744.x

Kindt, R., Breugel, P., Lillesø, J.-P. B., Gachathi, F., and Graudal, L. (2014). Potential Natural Vegetation of Eastern Africa Vol. Volume 8 (Ethiopia, Kenya, 
Malawi, Rwanda, Tanzania, Uganda and Zambia: Atlas and Tree Species Composition for Kenya).

Kumagai, T., Kuraji, K., Noguchi, H., Tanaka, Y., Tanaka, K., and Suzuki, M. (2001). Vertical profiles of environmental factors within tropical rainforest, Lambir Hills National Park, Sarawak, Malaysia. J. For. Res. 6, 257-264. doi: 10.1007/BF02762466

Lewis, S. L., Lopez-Gonzalez, G., Sonké, B., Affum-Baffoe, K., Baker, T. R., Ojo, L. O., et al. (2009). Increasing carbon storage in intact African tropical forests. Nature 457, 1003-1006. doi: 10.1038/nature07771

Lewis, S. L. (2006). Tropical forests and the changing earth system. Philos. Trans. R. Soc Lond. B Biol. Sci. 361, 195-210. doi: 10.1098/rstb.2005.1711

Medlyn, B. E., Dreyer, E., Ellsworth, D., Forstreuter, M., Harley, P. C., Kirschbaum, M. U. F., et al. (2002). Temperature response of parameters of a biochemically based model of photosynthesis. II. A review of experimental data. Plant Cell Environ. 25, 1167-1179. doi: 10.1046/j.1365-3040.2002.00891.x

Meir, P., Kruijt, B., Broadmeadow, M., Barbosa, E., Kull, O., Carswell, F., et al. (2002). Acclimation of photosynthetic capacity to irradiance in tree canopies in relation to leaf nitrogen concentration and leaf mass per unit area. Plant Cell Environ. 25, 343-357. doi: 10.1046/j.0016-8025.2001.00811.x

Mujawamariya, M., Manishimwe, A., Ntirugulirwa, B., Zibera, E., Ganszky, D., Ntawuhiganayo Bahati, E., et al. (2018). Climate sensitivity of tropical trees along an elevation gradient in rwanda. Forests 9:647. doi: 10.3390/f9100647

Niinemets, U., and Tenhunen, J. D. (1997). A model separating leaf structural and physiological effects on carbon gain along light gradients for the shade-tolerant species Acer saccharum. Plant Cell Environ. 20, 845-866. doi: 10.1046/j.13653040.1997.d01-133.x

Nsabimana, D. (2009). Carbon stock and fluxes in Nyungwe forest and Ruhande Arboretum in Rwanda. PhD thesis, (Gothenburg: University of Gothenburg).

Ntawuhiganayo, E. B., Uwizeye, F. K., Zibera, E., Dusenge, M. E., Ziegler, C., Ntirugulirwa, B., et al. (2020). Traits controlling shade tolerance in tropical montane trees. Tree Physiol. 40, 183-197. doi: 10.1093/treephys/ tpz119

Nyirambangutse, B., Zibera, E., Uwizeye, F. K., Nsabimana, D., Bizuru, E., Pleijel, H., et al. (2017). Carbon stocks and dynamics at different successional stages in an Afromontane tropical forest. Biogeosciences 14, 1285-1303. doi: 10.5194/bg14-1285-2017

Onoda, Y., Wright, I. J., Evans, J. R., Hikosaka, K., Kitajima, K., Niinemets, Ü., et al. (2017). Physiological and structural tradeoffs underlying the leaf economics spectrum. New Phytol. 214, 1447-1463. doi: 10.1111/nph.14496

Pan, Y., Birdsey, R. A., Fang, J., Houghton, R., Kauppi, P. E., Kurz, W. A., et al. (2011). and persistent carbon sink in the world's forests. Science 333, 988-993. doi: 10.1126/science.1201609

Pepin, N., Bradley, R. S., Diaz, H. F., Baraer, M., Caceres, E. B., Forsythe, N., et al. (2015). Elevation-dependent warming in mountain regions of the world. Nat. Clim. Change 5, 424-430. doi: 10.1038/nclimate2563

Plumptre, A. J., Masozera, M., Fashing, P. J., McNeilage, A., Ewango, C., Kaplin, B. A., et al. (2002). Biodiversity Surveys of the Nyungwe Forest of Southwest Rwanda (Bronx, NY, USA: Working paper 19, Wildlife Conservation Society).

Plumptre, A. J., Davenport, T. R., Behangana, M., Kityo, R., Eilu, G., Ssegawa, P., et al. (2007). The biodiversity of the Albertine Rift. Biol. Conserv. 134 (2), 178194.

Poorter, H., Niinemets, Ü., Ntagkas, N., Siebenkäs, A., Mäenpää, M., Matsubara, S., et al. (2019). A meta-analysis of plant responses to light intensity for 70 traits ranging from molecules to whole plant performance. New Phytol. 223, 1073-1105. doi: 10.1111/nph.15754

Porté, A., and Loustau, D. (1998). Variability of the photosynthetic characteristics of mature needles within the crown of a 25 -year-old Pinus pinaster. Tree Physiol. 18, 223-232. doi: 10.1093/treephys/18.4.223

Raaimakers, D., Boot, R. G. A., Dijkstra, P., and Pot, S. (1995). Photosynthetic rates in relation to leaf phosphorus content in pioneer versus climax tropical rainforest trees. Oecologia 102, 120-125. doi: 10.1007/BF00333319

Reich, P. B., Oleksyn, J., and Wright, I. J. (2009). Leaf phosphorus influences the photosynthesis-nitrogen relation: a cross-biome analysis of 314 species. Oecologia 160, 207-212. doi: 10.1007/s00442-009-1291-3

Reich, P. B. (2014). The world-wide 'fast-slow' plant economics spectrum: a traits manifesto. J. Ecol. 102, 275-301. doi: 10.1111/1365-2745.12211
Rogers, A. (2014). The use and misuse of V(c,max) in Earth System Models. Photosyn. Res. 119, 15-29. doi: 10.1007/s11120-013-9818-1

Rozendaal, D. M. A., Hurtado, V. H., and Poorter, L. (2006). Plasticity in leaf traits of 38 tropical tree species in response to light; relationships with light demand and adult stature. Funct. Ecol. 20, 207-216. doi: 10.1111/j.1365-2435.2006.01105.x

Rutten, G., Ensslin, A., Hemp, A., and Fischer, M. (2015). Forest structure and composition of previously selectively logged and non-logged montane forests at Mt. Kilimanjaro. For. Ecol. Manage. 337, 61-66. doi: 10.1016/j.foreco.2014.10.036

Santiago, L. S., and Mulkey, S. S. (2003). A test of gas exchange measurements on excised canopy branches of ten tropical tree species. Photosynthetica 41, 343347. doi: 10.1023/B:PHOT.0000015457.92479.eb

Scatena, F.N., Bruijnzeel, L.A., Bubb, P., and Das, S. (2010). "Setting the stage," in Tropical montane cloud forests: science for conservation and management. Eds. L. A. Bruijnzeel, F. N. Scatena and L. S. Hamilton (Cambridge, United Kingdom: Cambridge University Press), 3-13.

Sholtis, J. D., Gunderson, C. A., Norby, R. J., and Tissue, D. T. (2004). Persistent stimulation of photosynthesis by elevated $\mathrm{CO} 2$ in a sweetgum (Liquidambar styraciflua) forest stand. New Phytol. 162, 343-354. doi: 10.1111/j.14698137.2004.01028.x

Spracklen, D. V., and Righelato, R. (2014). Tropical montane forests are a larger than expected global carbon store. Biogeosciences 11, 2741-2754. doi: 10.5194/ bg-11-2741-2014

Stocker, T. F., Qin, D., Plattner, G.-K., Tignor, M. M. B., Allen, S. K., Boschung, J., et al. (Eds.) (2014). Climate Change 2013: The Physical Science Basis. Contribution of Working Group I to the Fifth Assessment Report of IPCC the Intergovernmental Panel on Climate Change. (Cambridge: Cambridge University Press). doi: 10.1017/CBO9781107415324

Tesfaye, G., Teketay, D., and Fetene, M. (2002). Regeneration of fourteen tree species in Harenna forest, southeastern Ethiopia. Flora - Morphol. Distrib. Funct. Ecol. Plants 197, 461-474. doi: 10.1078/0367-2530-1210063

Thornton, P. E., Doney, S. C., Lindsay, K., Moore, J. K., Mahowald, N., Randerson, J. T., et al. (2009). Carbon-nitrogen interactions regulate climate-carbon cycle feedbacks: results from an atmosphere-ocean general circulation model. Biogeosciences 6, 2099-2120. doi: 10.5194/bg-6-2099-2009

Tissue, D. T., Griffin, K. L., Turnbull, M. H., and Whitehead, D. (2005). Stomatal and non-stomatal limitations to photosynthesis in four tree species in a temperate rainforest dominated by Dacrydium cupressinum in New Zealand. Tree Physiol. 25, 447-456. doi: 10.1093/treephys/25.4.447

Uddling, J., Gelang-Alfredsson, J., Piikki, K., and Pleijel, H. (2007). Evaluating the relationship between leaf chlorophyll concentration and SPAD-502 chlorophyll meter readings. Photosyn. Res. 91, 37-46. doi: 10.1007/s11120006-9077-5

Valladares, F., and Niinemets, Ü. (2008). Shade Tolerance, a Key Plant Feature of Complex Nature and Consequences. Annu. Rev. Ecol. Evol. Syst. 39, 237-257. doi: 10.1146/annurev.ecolsys.39.110707.173506

Valladares, F., Laanisto, L., Niinemets, Ü., and Zavala, M. A. (2016). Shedding light on shade: ecological perspectives of understorey plant life. Plant Ecol. Divers. 9, 237-251. doi: 10.1080/17550874.2016.1210262

van de Weg, M. J., Meir, P., Grace, J., and Ramos, G. D. (2012). Photosynthetic parameters, dark respiration and leaf traits in the canopy of a Peruvian tropical montane cloud forest. Oecologia 168, 23-34. doi: 10.1007/s00442011-2068-z

van de Weg, M. J., Meir, P., Williams, M., Girardin, C., Malhi, Y., Silva-Espejo, J., et al. (2014). Gross primary productivity of a high elevation tropical montane cloud forest. Ecosystems 17, 751-764. doi: 10.1007/s10021-014-9758-4

Walker, A. P., Beckerman, A. P., Gu, L., Kattge, J., Cernusak, L. A., Domingues, T. F., et al. (2014). The relationship of leaf photosynthetic traits - V cmax and J max - to leaf nitrogen, leaf phosphorus, and specific leaf area: a meta-analysis and modeling study. Ecol. Evol. 4, 3218-3235. doi: $10.1002 /$ ece3.1173

Wright, I. J., Reich, P. B., Westoby, M., Ackerly, D. D., Baruch, Z., Bongers, F., et al. (2004). The worldwide leaf economics spectrum. Nature 428, 821-827. doi: 10.1038/nature02403

Xiao, Y., Liu, S., Tong, F., Chen, B., and Kuang, Y. (2018). Dominant Species in Subtropical Forests Could Decrease Photosynthetic N Allocation to Carboxylation and Bioenergetics and Enhance Leaf Construction Costs during Forest Succession. Front. Plant Sci. 9:117:117. doi: 10.3389/ fpls.2018.00117 
Zaehle, S., Friedlingstein, P., and Friend, A. D. (2010). Terrestrial nitrogen feedbacks may accelerate future climate change. Geophys. Res. Lett. 37, n/an/a. doi: 10.1029/2009GL041345

Zhang, G., Zhang, L., and Wen, D. (2018). Photosynthesis of subtropical forest species from different successional status in relation to foliar nutrients and phosphorus fractions. Sci. Rep. 8, 10455. doi: 10.1038/ s41598-018-28800-4

Zuur, A. F., Ieno, E. N., Walker, N. J., Saveliev, A. A., and Smith, G. M. (2009). "Mixed Effects Modelling for Nested Data," in Mixed effects models and extensions in ecology with R Statistics for Biology and Health (New York, NY: Springer New York), 101-142. doi: 10.1007/978-0-387-87458-6_5
Conflict of Interest: The authors declare that the research was conducted in the absence of any commercial or financial relationships that could be construed as a potential conflict of interest.

Copyright (C) 2020 Ziegler, Dusenge, Nyirambangutse, Zibera, Wallin and Uddling This is an open-access article distributed under the terms of the Creative Commons Attribution License (CC BY). The use, distribution or reproduction in other forums is permitted, provided the original author(s) and the copyright owner(s) are credited and that the original publication in this journal is cited, in accordance with accepted academic practice. No use, distribution or reproduction is permitted which does not comply with these terms. 